\title{
Toy Fox Terrier
}

National Cancer Institute

\section{Source}

National Cancer Institute. Toy Fox Terrier. NCI Thesaurus. Code C53945.

The Toy Fox Terrier is also known as the American Toy Terrier or Amertoy. The eyes are dark and round and the ears are v-shaped and erect. The coat is short and thick and comes in white with black and tan or tan markings. Other colors do occur. Height: about 10 inches $(25 \mathrm{~cm}$.) Weight: $3.5-7$ pounds $(1.5-3 \mathrm{~kg}$.) 